\title{
Inhibitory Effect of Lactic Acid Bacteria on Aflatoxin B1 Producing Aspergillus flavus Isolated from Garri
}

\author{
O. J. Egbere, C. E. Odu, I. A. Onyimba, A. C. Ngene, M. M. Dashen, A. O. Ogaji, \\ W. N. Hemen, and E. E. Entonu
}

\section{ABSTRACT}

\begin{abstract}
Among the potential benefits of probiotic lactic acid bacteria (LAB) is their practical use for biopreservation of foods, fungal decontamination, and novel biotherapy. A number of ready to eat foods hawked in streets of Nigeria such as garri are prone to contamination by mycotoxin-producing fungi. In this study the inhibitory effect of lactic acid bacteria (LAB) (sourced from local foods (nono and kunun- zaki)) and their bacteriocinsderivatives on aflatoxin B1 -producing Aspergelius flavus was conducted. Out of the five LAB isolates screened three (two strains of Lactococcus and one of Pediococcus sp had high indices of probiotic potentials and bacteriocins extracts were obtained from them and used for the inhibition study. Fourty samples of garri sold in Jos metropolis were screened for $\boldsymbol{A}$. flavus and their abilities to produce Aflatoxin B1 using the Coconut Extract Agar (CEA) and Ammonia Vapour Test (AVP) methods. The three most probiotic $L A B$ and their respective crude baterioncin extracts were used to test for their inhibitory effect on aflatoxin producing $A$. flavus isolates. The results of the study showed that while only 17 samples $(42.50 \%)$ had $A$. flavus in them, only three of the fungi $((\mathbf{1 7 . 6 5 \%})$ demonstrated capacity to produce Aflatoxin B1, making $\mathbf{7 . 5 \%}$ of the total number of garri samples that had aflatoxin-producing $A$. flavus. The inhibition of fungal growth by LAB and bacteriocins was dose dependent. At an inoculum concentration of $1 \mathrm{ml}$, Pediococcus sp had the highest mean zone of inhibition of $43.0 \mathrm{~mm}$ followed by Lactococcus sp (Strain LAC20G with radial diameter $38.0 \mathrm{~mm}$ and Lactococcus sp (LAC20G) which had a radial diameter of $29.3 \mathrm{~mm}$ respectively. The results of the study portend that the growth of aflatoxin producing Aspergillus flavus in ready to eat foods such as garri could be prevented by application of appropriate dosages of bacteriocins extracts from lactic acid bacteria.
\end{abstract}

Keywords: Aflatoxin, Aspergelius flavus, bacteriocin, garri, lactic acid bacteria.
Published Online: January 13, 2022

ISSN: $2684-5199$

DOI : $10.24018 /$ ejbio.2022.3.1.242

\section{O. J. Egbere*}

Department of Microbiology, Faculty of Natural Sciences, University of Jos, Nigeria.

(e-mail: egbereo@yahoo.com)

\section{E. Odu}

Department of Biological Sciences, Faculty of Natural Sciences, University of Maiduguri, Nigeria.

I. A. Onyimba

Department of Science Laboratory Technology, Faculty of Natural Sciences, University of Jos, Nigeria.

A. C. Ngene

Department of Microbiology, College of Natural Sciences, Michael Okpara University of Agriculture, Umudike, Nigeria.

M. M. Dashen

Department of Microbiology, Faculty of Natural Sciences, University of Jos, Nigeria.

A. O. Ogaji

Department of Microbiology, Faculty of Natural Sciences, University of Jos, Nigeria.

W. N. Hemen

Fidei Polytechnic, Gboko, Nigeria.

E. E. Entonu

Department of Microbiology, Faculty

of Natural Sciences, University of Jos, Nigeria.

*Corresponding Author

\section{INTRODUCTION}

About $25 \%$ of the global food output is contaminated by mycotoxin causing significant economic losses (Ostry et al., 2017). Aflatoxins are the most common, widespread, and most potent of all mycotoxins that contaminate food, and aflatoxin B1 (AFB1) commonly produced by A. flavus is responsible for about $75 \%$ of all aflatoxin contamination of foods (Zhang et al., 2012) with a distribution of $43.75 \%$ in African countries as reported by (Darwish et al., 2014). The World Health Organization (WHO) report indicates that over 500 million of the poorest are exposed to unsafe mycotoxins levels, most of which live in Sub-Saharan Africa, and in Nigeria, contaminations of various food commodities have been reported across all the agro-ecological zones. The world health organization (WHO) in 2018 reported that an aflatoxin concentration of $1 \mathrm{mg} / \mathrm{kg}$ or higher has been suspected to cause aflatoxicosis and aflatoxin B1 (AFB1) dose of 20$120 \mathrm{microgram} / \mathrm{kg} \mathrm{BW}$ per day is acutely toxic and potentially lethal (WHO, 2018) and according to (Wagacha \& Muthomi, 2008). Due to diseases exacerbated by aflatoxin, $40 \%$ productivity loss has been incurred in developing countries. Garri is a staple, consumed by many people, and are exposed to contamination by toxigenic fungi especially those that produce aflatoxins which may be pre-harvest, post-harvest, processing phenomena, or during storage. It is hygroscopic and can absorb moisture which supports the growth of aflatoxigenic fungi.

Little or no work has been done in respect to reduction of aflatoxin in gari particularly, and not so much attention has 
been paid as regards aflatoxin detection and reduction in gari bringing to bear that it is widely consumed as well as recognition of the fact that it is prone to contamination by aflatoxin B1 producing Aspergillus flavus and its dangers to human health. The LD50, that is, the amount or dose that is fatal to $50 \%$ of a population exposed to AFB1 is at or less than $18 \mathrm{mg} / \mathrm{kg} \mathrm{BW}$ (Kate, 2019) and more worrying of all is that normal boiling temperature cannot decontaminate foods containing aflatoxins except at sterilization temperature as decomposition temperature is at about $237-306^{\circ} \mathrm{C}$ (Jalili \& Scotter, 2015). Although, bacteriocin has been found effective in inhibiting the growth of microorganism including fungi little have been done concerning aflatoxin B1 (AFB1) producing $A$. flavus isolated from garri.

Aflatoxins are a problem of worldwide importance in public health, agriculture, and economics (Trucksess et al., 1977) with a significant impact on the health and further, the economy of a nation. The safety and quality of food are of importance if such food should be consumed especially ready to eat foods, justifying the need to identify aflatoxigenic fungi such as Aspergillus flavus capable of growth and contamination of street vend garri and the presence of aflatoxin B1 (AFB1) as their presence in foods could pose health challenges due to increasing cancer and immunosuppression. Lactic acid bacteria (LAB) and their bacteriocins have recently been of significant commercial interest as a natural food preservative to increase food safety and stability. Garri is a food staple in Nigeria consumed by millions of people (Tolulope \& Godbless, 2015) (45-50\% of the population), are prone to contamination by aflatoxin B1 (AFB1) producing A.flavus, and little or no work is available on it been decontaminated. The study, therefore, will go a long way as a contribution towards identifying more lactic acid bacteria isolated from local sources (e.g Nono, Kununzaki, etc.) capable of inhibiting the growth of aflatoxin B1 producing A. flavus isolated from garri. This research aims to determine the inhibitory effects of lactic acid bacteria (LAB) on aflatoxin B1 producing Aspergillus flavus isolated from garri sold in Jos metropolis.

\section{MATERIALS AND Methods}

\section{A. Collection of Aspergillus flavus Isolates}

A total of $17 \mathrm{~A}$. flavus isolated from 40 garri samples were collected from the University of Jos Microbiology Laboratory.

\section{B. Confirmation of A. flavus Identity}

Re-identification of $A$. flavus isolates was done by seeding pure isolate on PDA and incubated at $25+2{ }^{\circ} \mathrm{C}$ for 5-7 days. After incubation, macroscopic observation of colonies was done, and microscopy of distinct colonies also was carried out as well using lactophenol cotton blue. The morphological characteristics of $A$. flavus isolates were described microscopically according to (Klich, 2002).

\section{Test for Aflatoxin B1 Producing A. flavus}

1) Coconut-Based Medium - UV Test for Detection of Aflatoxin Producing A. flavus

Screening for aflatoxin production potentials was carried on coconut extract agar (CEA) with $40 \mu \mathrm{g} / \mathrm{ml}$ chloramphenicol to suppress bacterial growth, following standard methods (Davis et al., 1987). All the pure fungal isolates were inoculated on CEA and incubated at $27^{\circ} \mathrm{C}$ for 5 days. By observing reversed sides of plates under $365 \mathrm{~nm}$ ultraviolet lamb, the aflatoxin-producing potential of the isolates was determined. The emission of a characteristic blue fluorescence confirmed the presence of aflatoxin-producing potentials of the isolates with inoculated CEA as medium control.

\section{2) Ammonia Vapor Test for Detection of Aflatoxin Producing A. flavus}

The fungal isolates were inoculated on CEA as single colonies by cork borer $(5 \mathrm{~mm})$ diameter in the center of the plate and incubated in the dark at $28^{\circ} \mathrm{C}$ for 7 days. The dish was inverted, and 1 or 2 drops of concentrated ammonium hydroxide solution were placed on the inside of the lid of the Petri dish. Over the lid containing ammonium hydroxide, the agar plates were inverted. A control was prepared as mentioned above.

D. Collection of Lactic Acid Bacterial Isolates and Identification

A total of thirteen (13) different Lactic Acid Bacteria isolated from Kunun-zaki and Nono were collected from the University of Jos microbiology Lab. and re-identified. Identification was done by observation of morphological characteristics, microscopic appearance, and biochemical testing.

\section{RESUlts}

The morphological, microscopic, as well as biochemical characteristics of the lactic acid bacteria isolated from Nono and Kunun-Zaki samples from various locations in Jos, were characterized. Morphological characteristics observed include size color, colony elevation, margin, and shape. Six of the isolates were gram-positive, catalase-negative, oxidase negative most of which appear cocci in pairs, and short rods were under the microscope, the rest were catalase-positive and gram-negative. Sugar fermentation tests done on cocci isolates that are gram-positive and catalase-negative using six different sugars which includes sucrose, glucose, fructose, mannose, lactose, maltose reveals four isolates showed different levels of fermentation of the different sugars which was observed by a change of color from purple to yellow showing acid production. Production of gas in Durham tubes was also observed. Three isolates were selected identified as Pediococcus sp. and Lactococcus sp. A and B.

Probiotic potentials testing was carried out on the isolates. Antibacterial susceptibility tests of the isolates to three different test organisms which include S. aureus, E. coli, Bacillus sp. and level of inhibition is represented by a zone of inhibition as shown in Table II below $S$. aureus was susceptible to all five lactic acid bacteria with a zone of inhibition of 23, 22, 28, 20, $21 \mathrm{~mm}$, E. coli was susceptible to 2 and Bacillus sp. to (3) three of lactic acid bacteria. All lactic acid bacteria isolates showed different tolerance to $\mathrm{NaCl}$ at a different concentration as represented in the chart (Fig. 1) below. Determination of milk coagulation prototype $1 \%(\mathrm{v} / \mathrm{v})$ of the probiotic culture bacteria was done. Determination of tolerance of the isolates to phenol at different concentrations 
carried out showed all isolate tested showed a different level of tolerance to phenol as represented in Table III.

TABLE I: ANTIMICROBIAL SENSITIVITY TESTING OF LACTIC ACID BACTERIA ISOLATES FROM KUNUN-ZAKI AND NONO

\begin{tabular}{ccccc}
\hline \multicolumn{2}{c}{ Bsolate Name } & $\begin{array}{c}\text { Isolate } \\
\text { Code }\end{array}$ & \multicolumn{3}{c}{ Zone of Inhibition (mm) } \\
& & S. aureus & E. coli & Bacillus $s p$ \\
\hline \hline Pediococcus $s p$. & LCG20A & 23 & 15 & 21 \\
Lactococcus $s p$. & LCG20F & 22 & $\mathrm{R}$ & $\mathrm{R}$ \\
Lactococcus $s p$. & LCG20G & 28 & 21 & 25 \\
Pediococcus $s p$. & LCG20J & 20 & $\mathrm{R}$ & $\mathrm{R}$ \\
Lactococcus $s p$. & LCG20M & 21 & $\mathrm{R}$ & 5 \\
\hline \hline
\end{tabular}

TABLE II: PROBIOTIC Potentials OF LACTIC ACID BACTERIA USING PHENOL TOLERANCE TEST AS AN INDEX

\begin{tabular}{cccc}
\hline \hline Conc. Of Phenol: & $0.10 \%$ & $0.30 \%$ & $0.60 \%$ \\
\hline \hline LAB Isolate & \multicolumn{3}{c}{ Absorbance (nm) } \\
\hline $\begin{array}{c}\text { LCG20A } \\
\text { (Pediococcus sp.) } \\
\text { LCG20G }\end{array}$ & 0.4 & 0.42 & 0.39 \\
$\begin{array}{c}\text { (Lactococcus sp.) } \\
\text { LCG20M } \\
\text { (Lactococcus sp.) }\end{array}$ & 0.48 & 0.42 & 0.25 \\
\hline \hline
\end{tabular}

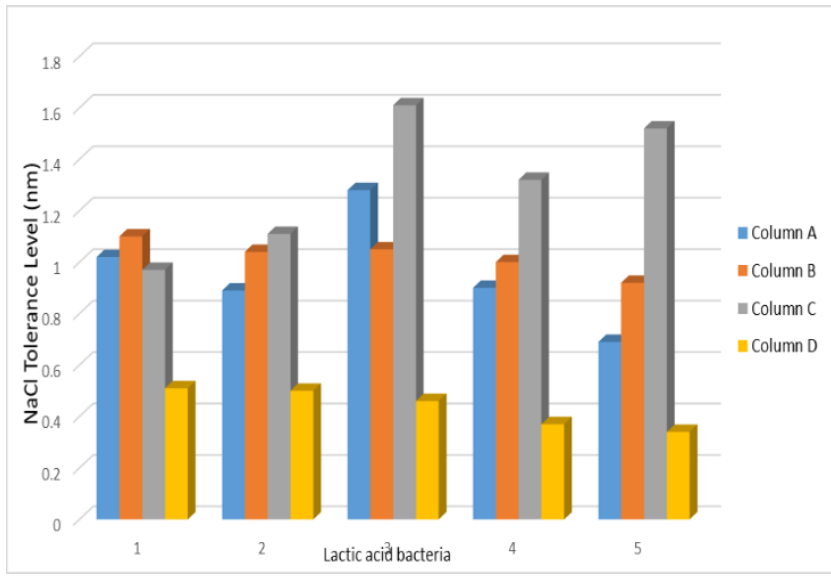

Fig. 1. Probiotic Potential Measured by $\mathrm{NaCl}$ Tolerance of Lactococcus $\mathrm{sp}$ and Pediococcus sp Isolated from kunun-zaki and Nono.

Key: Column; A = sample LCG20A, B = sample LCG20F, C = sample LCG20G, D = samples LCG20M.

Seventeen $A$. flavus isolated from forty gari samples from four markets in Jos metropolis were considered. Detection of aflatoxin B1 and non-aflatoxin B1 isolated using Coconut based - U.V and ammonium vapor test revealed that out of the seventeen (17) A. flavus isolates that were isolated from the 40 garri samples representing a presence frequency of
$42.5 \%, 3(17.6 \%)$ isolates coded as Af05-Gby1, Af09-Ty1 and Af10-Ty2 were aflatoxin B1 positive in both methods (Table IV). The detection by UV light at $365 \mathrm{~nm}$ recognized aflatoxigenic by the production of blue-green fluorescent colonies in the center of glass Petri dish of CEA in the reverse, from non-florescence non inoculated CEA plate.

The inhibitory effect of the bacteriocin producer isolates identified as Pediococcus sp. and Lactococus sp A and B tested using a modified overlay method of Magnusson and Schnurer (2001), showed a different level of inhibition. The LAB isolates assayed for possible inhibition of the Aspergillus flavus isolates result is as shown in Table IV. All the LAB isolates inhibited at least one aflatoxin B1producing A. flavus isolate to varying extents. The highest inhibition (32 mm) was observed with Pediococcus sp against all three A. flavus isolates. Least inhibition was observed with Lactococcus sp (B) inhibiting only A. flavus (Af09-Ty1) with a zone of inhibition of $14 \mathrm{~mm}$. The inhibitory effect of the crude lactic acid bacteria bacteriocin extracts was also tested by inoculating $2 \mathrm{ml}, 1 \mathrm{ml}$ of stock $A$. flavus mycelia solution as well as $1 \mathrm{ml}$ of dilution 101, 102, 103, and 104 on PDA by pour plate method. Pediococcus sp has the highest zone of inhibition of $35 \mathrm{~mm}$ at the lowest mycelia dilutions of $2 \mathrm{ml}$ of stock mycelia solution on A. flavus (Af05-Gby1), Lactococcus sp (A) has the highest zone of $25 \mathrm{~mm}$ on $A$. flavus (Af05-Gby1) and Lactococcus sp. (B) has the highest zone of inhibition of $20 \mathrm{~mm}$ on A. flavus Af09-Ty1 and Af10Ty2. Maximum Zone of inhibition observed by Pediococcus sp, Lactococcus sp (A), and Lactococcus sp. B at highest mycelia dilution of $0.0001 / \mathrm{ml}$ are 58,56 and $48 \mathrm{~mm}$, respectively on $A$. flavus isolate Af10-Ty2, Af09-Ty1, and Af05-Ty1 respectively, measured in millimeters is shown in Table V.

TABLE III: INHIBITORY EFFECT OF LACTIC ACID BACTERIAON AFLATOXIN B1 PRODUCING A. FlAVUS ISOLATES OBTAIN FROM GARI SAMPLES

\begin{tabular}{cccc}
\hline \hline LAB Isolates & \multicolumn{3}{c}{ Aflatoxin Producing A. flavus Isolates } \\
\hline \hline & Af05-Gby1 & Af09-Ty1 & Af10-Ty2 \\
\hline \hline LCG20A & ++ & ++ & ++ \\
Pediococcus sp. & & & + \\
LCG20G & + & - & - \\
Lactococcus sp. & & & + \\
LCG20M & - & + & - \\
Lactococcus sp. & & - & - \\
Control (-) & - & - & + \\
\hline \hline
\end{tabular}

Key: - = No inhibition, $+=$ Inhibition $<30 \mathrm{~mm},++=$ Inhibition $>30 \mathrm{~mm}$, $+++=$ Inhibition.

\begin{tabular}{|c|c|c|c|c|c|}
\hline \multirow[b]{2}{*}{ Location } & \multirow{2}{*}{$\begin{array}{l}\text { Total no } \\
\text { of sample }\end{array}$} & \multicolumn{4}{|c|}{ Occurrence of AfB1 producing A.flavus } \\
\hline & & $\begin{array}{l}\text { No. of } \\
\text { A.flavus }\end{array}$ & $\%$ & $\begin{array}{c}\text { No. of AfB1 positive A. flavus in both Coconut } \\
\text { bases medium and Ammonia vapor test }\end{array}$ & $\%$ \\
\hline Bukuru & 10 & 2 & 20.00 & 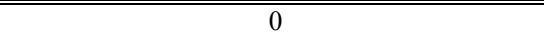 & 0.00 \\
\hline Gada-biu & 10 & 5 & 50.00 & 1 & 20.00 \\
\hline Taminus & 10 & 5 & 50.00 & 2 & 20.00 \\
\hline Chobe & 10 & 5 & 50.00 & 0 & 20.00 \\
\hline Total & 40 & 17 & & 3 & 17.60 \\
\hline
\end{tabular}


TABLE V: INHIBITORY EFFECT OF EXTRACTS OF BACTERIOCIN FROM LAB ON VARYING CONCENTRATION OF MYCELIA OF ASPERGILLUS FLAVUS MEASURED BY ZONE OF INHIBITION

\begin{tabular}{|c|c|c|c|c|c|}
\hline \multirow{3}{*}{$\begin{array}{l}\text { AFB1-producing } \\
\text { isolate }\end{array}$} & \multirow{3}{*}{$\begin{array}{l}\text { Conc. of } A . \text { flavus } \\
\text { mycelia (ml/Conc.) }\end{array}$} & \multicolumn{4}{|c|}{ Lactic acid bacteria Crude extract $(0.1 \mathrm{ml})$} \\
\hline & & $\begin{array}{c}\text { Pediococcus } \\
\text { sp.(LCG20A) } \\
\end{array}$ & $\begin{array}{c}\text { Lactococcus } \\
\text { sp.(LCG20G) } \\
\end{array}$ & $\begin{array}{c}\text { Lactococcus } \\
\text { sp.(LCG20M) } \\
\end{array}$ & Mean zone of inhibition \\
\hline & & $(\mathrm{mm})$ & $(\mathrm{mm})$ & $(\mathrm{mm})$ & \\
\hline \multirow{6}{*}{ Af05-Gby1 } & 2 & 35 & 25 & 15 & $25.00 \pm 10.00$ \\
\hline & 1 & 38 & 40 & 30 & $36.00 \pm 5.29$ \\
\hline & 0.1 & 40 & 45 & 40 & $41.60 \pm 2.89$ \\
\hline & 0.01 & 45 & 48 & 42 & $45.00 \pm 3.00$ \\
\hline & 0.001 & 50 & 55 & 44 & $49.70 \pm 5.50$ \\
\hline & 0.0001 & 56 & 55 & 48 & $53.00+4.36$ \\
\hline \multirow{6}{*}{ Af09-Ty1 } & 2 & 20 & 15 & 20 & $18.30 \pm 2.89$ \\
\hline & 1 & 45 & 45 & 28 & $39.30 \pm 9.81$ \\
\hline & 0.1 & 55 & 55 & 35 & $48.30 \pm 11.55$ \\
\hline & 0.01 & 50 & 58 & 40 & $49.30 \pm 9.01$ \\
\hline & 0.001 & 55 & 55 & 42 & $50.76 \pm 7.51$ \\
\hline & 0.0001 & 56 & 56 & 40 & $50.76 \pm 9.24$ \\
\hline \multirow{6}{*}{ Af10-Ty2 } & 2 & 24 & 20 & 20 & $21.30 \pm 2.31$ \\
\hline & 1 & 40 & 30 & 30 & $33.30 \pm 5.77$ \\
\hline & 0.1 & 46 & 35 & 32 & $37.70 \pm 2.08$ \\
\hline & 0.01 & 50 & 48 & 38 & $45.30 \pm 6.43$ \\
\hline & 0.001 & 54 & 55 & 40 & $49.70 \pm 8.39$ \\
\hline & 0.0001 & 58 & 55 & 45 & $52.70+6.81$ \\
\hline
\end{tabular}

P-values: Af05-Gby1=0.2323, Af09-Ty1=0.0004, Af10-Ty2 =0.1034 (Alpha value $=0.05)$.

$\mathrm{P}$-value for mean zone of inhibition $=0.6576$
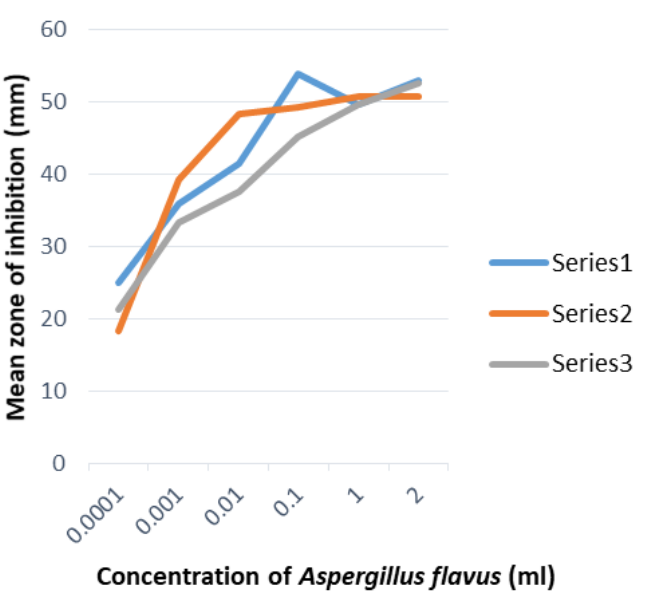

Fig. 2 Mean Zone of Inhibition Curve of Bacteriocins against Varying Aspergillus flavus Mycelia Concentration.

(Series 1, 2 and 3 represented by color blue, red and grey curve is the Mean Zone of inhibition of bacteriocins extract in $\mathrm{mm}$ against a concentration of A. flavus Af05-Gby1, Af09- Ty1 and Af10- Ty2 respectively in $\mathrm{ml}$.

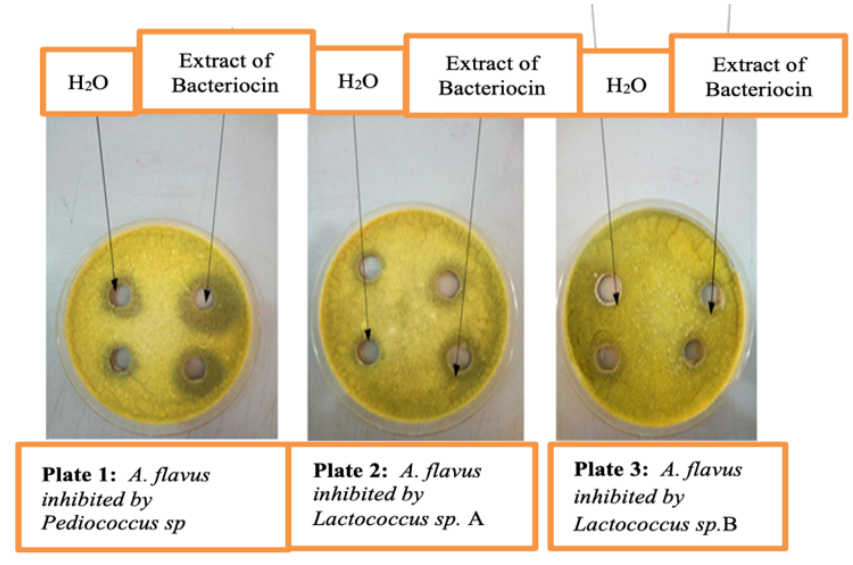

Fig. 3. Inhibition of Aspergillus flavus by crude extract of bacteriocin from Pediococcus sp, Lactococcus sp A and B respectively with distilled water (H2O) used as control on opposite wells.

\section{Discussion}

The study indicated that out of the total of thirteen (13) lactic acid bacteria isolated from kunun-zaki and Nono, five (5) cocci were tested for their antimicrobial effect out of which three (3) demonstrated antimicrobial effects. Organism identified includes Pediococcus sp, Lactococcus sp A and B with isolate code of LCG20A, LCG20G, and LCG20M respectively which conforms with the research findings of (Peyer, 2017) and that of (Okekeaji, 2017). They were the lactic acid bacteria (LAB) from which the bacteriocins were isolated and used for the test of their inhibitory effect on aflatoxin-producing Aspergillus flavus. Pediococcus sp and Lactococcus sp, which showed a higher degree of antimicrobial effect among all LAB tested, have been known for their bacteriocins producing potentials which agree with a report by (El-Nezami, 1998) on the ability of dairy strains of $\mathrm{LAB}$ to bind a common food carcinogen, aflatoxin $\mathrm{B} 1$ and (Savadogo et al., 2006) on Bacteriocins and lactic acid bacteria.

The research showed that three (3) (17.6\%) out of the 17 species of A. flavus produced aflatoxin B1. This result compares with those reported by (Klich, 2002). The difference between the aflatoxin-producing potential of these three could be due to several factors among which may include environmental conditions such as relative humidity, temperature, water activities medium type, etc. as reported by (Davis et al., 1987) and (O'Riordan \& Wilkinson, 2009).

It was shown that Pediococcus sp. had the highest inhibitory effect on aflatoxin-producing $A$. flavus followed by the Lactococcus sp. (coded as LCG20G). This study showed, however, that the effect of Pediococcus sp. on aflatoxin producing A. flavus is much higher than that of Lactococcus sp. which is slightly in variance with a study reported by (Onilude et al., 2005).

This study clearly demonstrated that the inhibitory effect of crude bacteriocins extracts was significantly higher on aflatoxin-producing $A$. flavus than those of the live organisms 
used. This is expected since the bacteriocins extract are indeed the major antagonistic principle behind the probiotic function of LAB (Aljewicz, \& Cichosz, 2017; Aljewicz et al., 2014; Aljewicz et al., 2014b).

\section{Statistical AnAlysis}

The inhibitory effects of the bacteriocins were dosedependent, this is proved by the significance in the $\mathrm{P}$-value $(<$ 0.05 ) of the mean zone of inhibition as clearly shown on the graph in Fig. 2.

\section{CONCLUSION}

The inhibitory effects of bacteriocins on aflatoxin-producing A. flavus increase with the increase in dose level of bacteriocin and vice versa. Identification of LAB with high ability as well as low dose level of bacteriocins capable of inhibiting aflatoxin producing Aspergillus flavus from ready to eat food will improve food safety and ensure sustainable quality of foods such as garri.

\section{CONCLUSION}

Lactic acid bacteria and their bacteriocin thus can be used as probiotics (as food supplements especially in widely consumed readily to eat foods such as garri) to inhibit the growth of aflatoxin producing Aspergillus flavus which may produce these toxins that have a deleterious health effect on humans. More studies should be done in this regard, by identifying more lactic acid bacteria isolated from different local sources, and their inhibitory effect is tested in comparison against toxigenic fungi especially aflatoxin B1 producing fungi as well as identifying factors that can influence the inhibitory effect of the lactic acid bacteria.

\section{REFERENCES}

Aljewicz, M., \& Cichosz, G. (2017). Influence of probiotic (Lactobacillus acidophilus NCFM, L. paracasei LPC37, and L. rhamnosus HN001) strains on starter cultures and secondary microflora in Swiss-and Dutch-type cheeses. Journal of Food Processing and Preservation, $41(6)$, e13253.

Aljewicz, M., Cichosz, G., Nalepa, B., \& Kowalska, M. (2014). Utjecaj probiotičkih kultura Lactobacillus acidophilus NCFM i Lactobacillus rhamnosus HN001 na proteolizu sira tipa Edam. Food Technology and Biotechnology, 52(4), 439-447.

Aljewicz, M., Siemianowska, E., Cichosz, G., \& Tońska, E. (2014). The effect of probiotics (Lactobacillus rhamnosus HN001, Lactobacillus paracasei LPC-37, and Lactobacillus acidophilus NCFM) on the availability of minerals from Dutch-type cheese. Journal of dairy science, 97(8), 4824-4831.

Aljewicz, M., Siemianowska, E., Cichosz, G., \& Tońska, E. (2014b). The effect of probiotics (Lactobacillus rhamnosus HN001, Lactobacillus paracasei LPC-37, and Lactobacillus acidophilus NCFM) on the availability of minerals from Dutch-type cheese. Journal of dairy science, 97(8), 4824-4831.

Darwish, W. S., Ikenaka, Y., Nakayama, S. M., \& Ishizuka, M. (2014). An overview on mycotoxin contamination of foods in Africa. Journal of Veterinary Medical Science, 76(6), 789-797.

Davis, N. D., Iyer, S. K., \& Diener, U. (1987). Improved method of screening for aflatoxin with a coconut agar medium. Applied and environmental microbiology, 53(7), 1593-1595.

El-Nezami, H., Kankaanpaa, P., Salminen, S., \& Ahokas, J. (1998). Ability of dairy strains of lactic acid bacteria to bind a common food carcinogen, aflatoxin B1. Food and chemical toxicology, 36(4), 321326.

Jalili, M., \& Scotter, M. (2015). A review of aflatoxin M1 in liquid milk. Iranian Journal of Health, Safety and Environment, 2(2), 283-295.

Kate, O. C. (2019). Fungal and aflatoxin occurrence in small-scale processed dry foodstuffs sold at informal retail outlets in the Johannesburg metropolis, South Africa (Doctoral dissertation).

Klich, M. A. (2002). Identification of common Aspergillus species. CBS.

Magnusson, J., \& Schnürer, J. (2001). Lactobacillus coryniformis subsp. coryniformis strain $\mathrm{Si} 3$ produces a broad-spectrum proteinaceous antifungal compound. Applied and environmental microbiology, 67(1), 1-5.

O’Riordan, M. J., \& Wilkinson, M. G. (2009). Comparison of analytical methods for aflatoxin determination in commercial chilli spice preparations and subsequent development of an improved method. Food Control, 20(8), 700-705.

Okekeaji, U. (2017). Diversity and Antibiogram of Microbial Contaminants Isolated from Foods Hawked in Nsukka Metropolis: Consideration for Public Health (Doctoral dissertation).

Onilude, A. A., Fagade, O. E., Bello, M. M., \& Fadahunsi, I. F. (2005). Inhibition of aflatoxin-producing aspergilli by lactic acid bacteria isolates from indigenously fermented cereal gruels. African Journal of Biotechnology, 4(12).

Ostry, V., Malir, F., Toman, J., \& Grosse, Y. (2017). Mycotoxins as human carcinogens - the IARC Monographs classification. Mycotoxin research, 33(1), 65-73.

Peyer, L. (2017). Lactic acid bacteria fermentation of wort as a tool to add functionality in malting, brewing and novel beverages (Doctoral dissertation, University College Cork).

Savadogo, A., Ouattara, A. C., Bassole, H. I., \& Traore, S. A. (2006). Bacteriocins and lactic acid bacteria-a minireview. African journal of biotechnology, 5(9).

Tolulope, A., \& Godbless, P. (2015). The mycological content of ready to eat garri in Amassoma, Bayelsa State. African Journal of Food Science, 9(2), 51-58.

Trucksess, M. W., Stoloff, L., Pons Jr, W. A., Cucullu, A. F., Lee, L. S., \& Franz Jr, A. O. (1977). Thin layer chromatographic determination of aflatoxin B1 in eggs. Journal of the Association of Official Analytical Chemists, 60(4), 795-798.

Wagacha, J. M., \& Muthomi, J. W. (2008). Mycotoxin problem in Africa: current status, implications to food safety and health and possible management strategies. International journal of food microbiology, $124(1), 1-12$.

World Health Organization (WHO). (February 2018). Food safety digest, department of food safety and Zoonosis, REF. No.:WHO/NHM/FOS/RAM/18.1; pp 2.

Zhang, Y., Shan, X., Shi, L., Lu, X., Tang, S., Wang, Y., ... \& Yan, H. (2012). Development of a fimY-based loop-mediated isothermal amplification assay for detection of Salmonella in food. Food Research International, 45(2), 1011-1015. 